\title{
Discussion: where do we go from here?
}

\section{Maurice Line}

Now that we can digitise more or less anything, how do we define information?

Jack Meadows

It has to be humanly usable, which is a small subset of all available information. We can even now use DNA to transmit information; a researcher recently took a strand of DNA, altered some of the molecules to carry encoded information, put it in an envelope and sent it to a colleague. The colleague was then able to decode the information carried in the DNA strand. So is the definition of information going to expand?

\section{Bob Campbell}

Could the librarians' role change? They are responsible for information going into organisations, rather than out of them; could this change to include getting information out of organisations more effectively?

\section{Jack Meadows}

In an organisation I visited, people responsible for receiving information via satellite were referred to as 'digital librarians'. This is not how I would define digital libraries, but it does show that given sufficient technical knowledge, the end user could be helped, and librarians would have the ability to plug into other communities.

\section{Brian Shackel}

At Loughborough University, every study bedroom in the halls of residence is being linked to the Internet, so why would a student ever find a need to visit the library in person?

\section{Jack Meadows}

There will inevitably be a transition period from print to electronic access. Students can and do access journals electronically, but they cannot access books that way, so they must visit the library. There will be a long transition period before the physical library is really not needed.

\section{Brian Shackel}

Not that long a transition - within five years everyone will be able to access the Internet. Furthermore, if students are going to be using the library less, what about making university libraries more open to outsiders?

\section{Jack Meadows}

It will reach saturation level, and maybe there won't be that many outsiders who have no access.

\section{Jennifer Rowland}

In many libraries there are lots of group study spaces, so maybe what is needed is study space rather than resources. 
Jack Meadows

Alan Sugar was recently interviewed, and said that if two students were told to search for information on copper, and one used the library and the other used the Internet, it would be the student using the library who came up with the relevant information first. 